\title{
Hypoxia-Inducible Factor-1 Activation by (-)-Epicatechin Gallate: Potential Adverse Effects of Cancer Chemoprevention with High-Dose Green Tea Extracts
}

\author{
Yu-Dong Zhou ${ }^{*}, \dagger$, , Yong-Pil Kim $\ddagger$, Xing-Cong Li†, Scott R. Baerson $§$, Ameeta K. \\ Agarwal ${ }^{\dagger}$, Tyler W. Hodges $\ddagger$, Daneel Ferreira ${ }^{\ddagger}$, and Dale G. Nagle ${ }^{\star}, \ddagger$ \\ National Center for Natural Products Research and Department of Pharmacognosy, Research \\ Institute of Pharmaceutical Sciences, School of Pharmacy, P.O. Box 1848, University of \\ Mississippi, University, MS 38677 and U.S. Department of Agriculture, Agricultural Research \\ Service, Natural Products Utilization Research Unit, P. O. Box 8048, University, Mississippi \\ 38677
}

\section{Abstract}

\begin{abstract}
Hypoxia-inducible factor-1 (HIF-1) is a transcription factor that induces oxygen-regulated genes in response to reduced oxygen conditions (hypoxia). Expression of the oxygen regulated HIF-1 $\alpha$ subunit correlates positively with advanced disease stages and poor prognosis in cancer patients. Green tea catechins are believed to be responsible for the cancer chemopreventive activities of green tea. We found that (-)-epicatechin-3-gallate (ECG, 1), one of the major green tea catechins, strongly activates HIF-1 in T47D human breast carcinoma cells. Among the green tea catechins tested, 1 demonstrated the strongest HIF-1 inducing activity while (-)-epigallocatechin-3-gallate (EGCG, 2), was significantly less active. However, $\mathbf{2}$ is relatively unstable in the in vitro system studied. Compound 1 also increases the expression of HIF-1 target genes including GLUT-1, VEGF, and CDKN1A. In T47D cells, 1 induces nuclear HIF-1 $\alpha$ protein without affecting HIF-1 $\alpha$ mRNA. Both the induction of HIF-1 $\alpha$ protein and activation of HIF-1 by 1 can be blocked by iron and ascorbate, indicating that $\mathbf{1}$ may activate HIF-1 through the chelation of iron. These results suggest that intended cancer chemoprevention with high-dose green tea extracts may be compromised, by the ability of tea catechins to promote tumor cell survival pathways associated with HIF-1 activation.
\end{abstract}

\begin{abstract}
Rapid tumor growth often outstrips the ability of blood vessels to supply oxygen and nutrients, leaving many regions inside solid tumors low in oxygen (hypoxia). In cancer patients, the extent of tumor hypoxia correlates positively with advanced disease stages, poor prognosis, and treatment resistance. ${ }^{1}$ Hypoxia-inducible factor-1 (HIF-1) is a transcription factor that plays a critical role in hypoxia activated gene expression. ${ }^{2}$ In tumor cells, HIF-1 activates the transcription of genes involved in anaerobic metabolism, angiogenesis, survival, invasion/metastasis and treatment resistance, thus promoting cellular
\end{abstract}

\footnotetext{
*Joint corresponding authors to whom correspondence should be addressed. Y.-D. Z.: Tel: (662) 915-1005. Fax: (662) 915-7062. ydzhou@ olemiss.edu. D. G. N.: Tel. (662) 915-7026. Fax: (662) 915-6975. dnagle@ olemiss.edu.

National Center for Natural Products Research.

*Department of Pharmacognosy.

§USDA, ARS-NPURU.

Supporting Information Available: Figure showing luciferase expression from a pGL3-Control construct in the presence of $\mathbf{1}$ and $\mathbf{2}$ under normoxic and hypoxic conditions; TLC analysis showing the stability of $\mathbf{1}$ and $\mathbf{2}$ in the presence of T47D cells under hypoxic conditions; and TLC analysis showing the stability of $\mathbf{2}$ when subjected to a panel of cell culture media and individual components. This material is available free of charge via the Internet at http://pubs.acs.org.
} 
adaptation and survival under hypoxic conditions. ${ }^{1,2}$ HIF-1 is a heterodimer of the bHLHPAS proteins HIF- $1 \alpha$ and HIF-1 $\beta$ /ARNT. HIF- $1 \alpha$ protein is degraded rapidly under normoxic conditions and stabilized under hypoxic conditions, while HIF-1 $\beta$ protein is constitutively expressed. Overexpression of the HIF-1 $\alpha$ subunit has been observed in many human cancers, and increased levels of HIF- $1 \alpha$ protein correlate with advanced disease stages and poor prognosis. ${ }^{3}$ In multiple animal models, deletion of either HIF-1 $\alpha$ or HIF-1 $\beta$ gene is associated with reduced tumor vascularity and retarded tumor growth. ${ }^{4-8}$ Numerous studies on HIF-1 and cancer during the past decade support HIF-1 as an important molecular target for anti-cancer drug discovery and development. ${ }^{2,9}$

Small molecule HIF-1 inhibitors represent potential molecular-targeted therapeutic agents for cancer. The current agents that inhibit HIF-1 activity are also known regulators of other cellular pathways. ${ }^{2,9}$ While examining natural product-derived compounds for HIF-1 inhibitory activities, we found that the green tea catechins ECG (1) and EGCG (2) actually activate HIF-1 under normoxic conditions in a T47D human breast tumor cell-based reporter assay. The cancer chemopreventive functions of green tea [dried fresh leaves of the plant Camellia sinensis L. Ktze., (Theaceae)] are supported by laboratory, animal-based, and some epidemiological studies. ${ }^{10-12}$ Recently, a phase I clinical trial of oral green tea extracts has been completed in adult patients with solid tumors. ${ }^{13}$ Major green tea catechins including 1, 2, (-)-epicatechin (EC, 3), and (-)-epigallocatechin (EGC, 4) are believed to be responsible for green tea's cancer chemopreventive activities. However, mixed results have been obtained from epidemiological studies that have examined the connection between green tea and cancer. ${ }^{14}$ If green tea catechins can activate tumor cell survival programs through HIF-1, then this may represent one potential adverse effect of cancer chemoprevention with green tea. This undesired activity may contribute to the mixed results observed in clinical green tea cancer chemoprevention studies.

This study investigates the effects of green tea catechins and related compounds on HIF-1 activity in vitro. Among the compounds tested [1-4, (+)-catechin (5), and gallic acid (6)], only catechins that contain the 3-gallate moiety (1 and 2) activate HIF-1 in a T47D cellbased reporter assay. In addition, $\mathbf{1}$ inhibits HIF-1 activation under hypoxic conditions. Apart from one hydroxyl group, $\mathbf{1}$ and $\mathbf{2}$ are structurally identical. However, $\mathbf{2}$ is chemically less stable than $\mathbf{1}$. The focus of this study is the regulation of HIF-1 activity by ECG (1). The pathways and mechanisms involved in HIF-1 activation have been extensively studied. $1,2,9$ In the presence of oxygen, the HIF-1 $\alpha$ subunit is prolyl hydroxylated, recognized by an E3 ubiquitin ligase complex that contains the von Hippel-Lindau tumor suppressor protein (pVHL), polyubiquitylated, and degraded by the $26 \mathrm{~S}$ proteosome. ${ }^{15-17}$ The HIF-1 $\alpha$ protein is also asparaginyl hydroxylated to prevent HIF-1 activation. ${ }^{18}$ At reduced cellular oxygen levels, inhibition of HIF-1 $\alpha$ protein prolyl hydroxylation and degradation leads to an increase in HIF-1 $\alpha$ protein levels, ${ }^{15-17}$ and inhibition of HIF-1 $\alpha$ protein asparaginyl hydroxylation results in the activation of HIF-1 and its target genes. ${ }^{18}$ Both the prolyl and asparaginyl hydroxylases that modify HIF- $1 \alpha$ protein require ferrous ion as a co-factor. $15,16,18$ Iron chelators can stabilize HIF- $1 \alpha$ protein and activate HIF- $1 .{ }^{19}$ Ascorbate blocks HIF-1 activation by iron chelators but not by hypoxia. ${ }^{20}$ The ECG-mediated induction of HIF- $1 \alpha$ protein and activation of HIF- 1 can be reversed by the addition of iron ions or ascorbate, suggesting that $\mathbf{1}$ activates HIF-1 in a similar fashion as iron chelators. However, none of the previously studied iron chelators (desferrioxamine, desferri-exochelin, ciclopirox olamine, 2,2'-dipyridyl, and dibenzoylmethane) that activate HIF-1 under normoxic conditions inhibit hypoxic activation of HIF-1. ${ }^{19,21-23}$ Compound 1 (ECG) appears to play dual opposing roles that differentially regulate HIF-1 activity, depending on the concentration of oxygen in the cellular environment. 


\section{Results and Discussion}

\section{HIF-1 Activation by Green Tea Catechins - Structure-Activity Relationship}

While screening small molecule natural products for HIF-1 inhibitors, we observed that certain green tea catechins activate HIF-1 under normoxic conditions in a T47D human breast tumor cell-based reporter assay. The effects of four major green tea catechins (1-4) and two related compounds ( $\mathbf{5}$ and $\mathbf{6}$ ) on HIF-1 activity were further examined. The activity of HIF-1 was monitored using a luciferase reporter under the control of HRE from the erythropoietin gene (pTK-HRE3-luc). ${ }^{24,25}$ The HIF-1 activity following treatment with each compound ( $16 \mathrm{~h}$, normoxic conditions) is presented in Figure 1A. At the concentration of $100 \mu \mathrm{M}$, the catechins that contain the 3-gallate moiety ( $\mathbf{1}$ and $\mathbf{2})$ activated HIF-1. A more robust induction of HIF-1 activity was observed in the presence of $\mathbf{1}$ than in the presence of 2 (16.8-fold versus 3.6-fold increase). None of the other compounds showed any statistically significant effect on HIF-1 activity at the concentrations tested. Under hypoxic conditions $\left(1 \% \mathrm{O}_{2}\right) 19$, only $1(100 \mu \mathrm{M})$ exhibited greater than $50 \%$ inhibition of HIF-1 activation by hypoxia (79\% inhibition) (Figure 1B). A similar experiment was performed in T47D cells transfected with a control reporter construct (pGL3-Control). Compound 1 neither stimulated luciferase expression from the control construct under normoxic conditions nor inhibited it under hypoxic conditions (Supporting Information). These results suggest that the gallate moiety is required for HIF-1 regulatory activity. Aside from one additional hydroxyl group in $\mathbf{2}$, the structures of $\mathbf{1}$ and $\mathbf{2}$ are essentially identical. However, only $\mathbf{1}$ exhibited oxygen-related dual regulation of HIF-1 activities in T47D cells. EGCG (2) is unstable in aqueous solutions and antioxidants such as BHT have been shown to enhance stability of $\mathbf{2} .{ }^{12}$ The stability of $\mathbf{1}$ and $\mathbf{2}$ under hypoxic conditions was examined in our in vitro system. Compounds $\mathbf{1}$ and $\mathbf{2}$ (1.5 mg each) were added separately to T47D cells (at 100 $\mu \mathrm{M}$ final concentration) and exposed to hypoxic conditions for $16 \mathrm{~h}$. The conditioned media were collected and extracted, and the compounds subjected to normal phase TLC analysis. Both 1 and 2 produce a moderately strong $\mathrm{UV}_{254}$ quenching reaction that results in a dark $\mathrm{UV}$ absorbance on silica gel $\mathrm{G}$ impregnated with $\mathrm{UV}_{254}$-absorbing fluorescence indicator (Supporting Information). These substances also produce characteristic color reactions upon treatment with $\mathrm{FeCl}_{3}$ and heat charring (Supporting Information). Compound $\mathbf{1}$ extracted from the conditioned media is chromatographically identical with a standard sample (strong $\mathrm{UV}_{254}$ quenching reaction and blue $\mathrm{FeCl}_{3}$ charring reaction). However, 2 could not be detected in the extract where it was incubated with T47D cells. An expanded secondary study of the chemical stability of $\mathbf{2}$ was performed (Supporting Information). In these experiments, samples of $\mathbf{2}$ (\#1 through \#4) were incubated with various modified media under hypoxic conditions, extracted from the treated media and analyzed by TLC along side of $\mathbf{2}, \mathbf{3}, \mathbf{4}$, and $\mathbf{6}$ standards. In the case of sample \#5, 2 was mixed with DMEM/F12 media supplemented with FCS (5\%, v/v) and Pen/Strep and immediately extracted as an incubation $\mathrm{t}_{0}$ control for extraction efficiency and stability under extraction conditions. Compound 2 that is chromatographically identical to the $\mathbf{2}$ standard was efficiently extracted with no significant decomposition. However, no $\mathbf{2}$ could be detected from extracts following incubation with T47D cells in 5\% FCS medium with antibiotics (sample 1), cell-free 5\% FCS medium with antibiotics (sample 2), cell-free medium with antibiotics (sample 3), or cell-free medium (sample 4). In samples \#1 to \#4, 2 was replaced by two, chromatographically distinct degradation products. Specifically, an orange-charring compound and a UV-active compound that does not produce a char reaction with $\mathrm{R}_{\mathrm{f}}$ values lower than that of the $\mathbf{2}$ standard. Subsequent attempts to isolate and characterize the degradation products by NMR were unsuccessful since these products appear to rapidly undergo further decomposition to an unrecognizable, perhaps polymeric, product. These results indicate that $\mathbf{2}$ is chemically unstable in DMEM/F12 medium. Rapid degradation of $\mathbf{2}$ may contribute to the observed difference in HIF-1 regulatory activity between $\mathbf{1}$ and $\mathbf{2}$. 


\section{ECG (1) Induces HIF-1 Target Genes through Stabilizing Nuclear HIF-1 $\alpha$ Protein}

To date, over 60 genes have been identified as direct targets of HIF-1. ${ }^{2}$ While most of these genes are induced by hypoxia in a cell type specific manner, genes such as VEGF, GLUT-1, and $C D K N 1 A$ (or $p 21^{\text {wafl } 1 / c i p l}$ ) are induced in most cell types. The effects of 1 on $V E G F$,

GLUT-1, and CDKN1A gene expression were examined. T47D cells were exposed to 1 (100 $\mu \mathrm{M})$ for $30 \mathrm{~min}$, followed by another $16 \mathrm{~h}$ incubation under normoxic and hypoxic $\left(1 \% \mathrm{O}_{2}\right)$ conditions. Total RNA samples were prepared from both control and treated cells. The levels of VEGF, GLUT-1, and CDKN1A mRNA in the total RNA samples were determined by quantitative real time RT-PCR and normalized to that of the internal control $18 \mathrm{~S}$ rRNA (Figure 2A). ${ }^{26}$ Under normoxic conditions, 1 induced all three genes examined. The levels of GLUT-1 and VEGF mRNA in the sample treated with $\mathbf{1}$ were twice that produced by the sample exposed to hypoxia. Although 1 inhibited hypoxic activation of HIF-1 (Figure 1B), it did not inhibit hypoxic induction of GLUT-1 and VEGF mRNAs (Figure 2A). Actually, the levels of GLUT-1 and VEGF mRNA in the sample of $\mathbf{1}$ exposed to hypoxia are comparable to levels observed in the sample of $\mathbf{1}$ incubated under normoxic conditions. A similar pattern of induction was observed for CDKN1A mRNA, although at a reduced level. VEGF is among the most potent angiogenic factors identified to date. The levels of VEGF proteins in T47D cells treated with 1 were examined and the data shown in Figure 2B. The conditions for compound treatment and hypoxic exposure were the same as those described to obtain the total RNA samples. Treatment with $\mathbf{1}$ increased cellular VEGF proteins to a level similar to that observed under hypoxic conditions.

HIF-1 is a heterodimer of the HIF- $1 \alpha$ and HIF-1 $1 \beta$ subunits. Stabilization of the oxygenregulated HIF- $1 \alpha$ subunit is a key step in HIF-1 activation. The effect of 1 on HIF- $1 \alpha$ protein stability was examined. As shown in Figure 3A, treatment with $1(100 \mu \mathrm{M}, 4 \mathrm{~h})$ induces nuclear HIF- $1 \alpha$ protein without affecting the constitutively expressed HIF-1 $\beta$ protein. However, an opposite effect was observed under hypoxic conditions $\left(1 \% \mathrm{O}_{2}\right)$ - compound 1 inhibited the induction of nuclear HIF-1 $\alpha$ protein by hypoxia (Figure 3A). The levels of HIF- $1 \alpha$ mRNA in total RNA samples isolated from cells treated with $1(100 \mu \mathrm{M}, 16 \mathrm{~h})$ and control cells were determined by real time RT-PCR and the data shown in Figure 3B. Compound 1 neither increased HIF- $1 \alpha$ mRNA level under normoxic conditions nor decreased HIF-1 $\alpha$ mRNA level under hypoxic conditions. These results suggest that 1 regulates HIF-1 by modulating the availability of nuclear HIF- $1 \alpha$ protein.

The anti-carcinogenic activities of green tea have been primarily attributed to the major green tea catechins (1-4), in particular, the most abundant and extensively studied 2 (EGCG) ${ }^{10-12}$ The proposed mechanisms of action range from scavenging reactive oxygen species to inhibiting enzymes key to cancer promotion and progression. Recent studies have established that 2 can act as a potential anti-angiogenic compound. ${ }^{27-32}$ In the present study, $2(100 \mu \mathrm{M})$ moderately activated HIF-1 under normoxic conditions and did not inhibit hypoxia-induced HIF-1 activation. Chemical stability studies suggest that the lack of stability of $\mathbf{2}$ in this cell-based in vitro system may contribute to its relatively weak HIF-1 regulatory activity. In comparison to $\mathbf{2}$, relatively few studies have been published that describe the biological activities associated with $\mathbf{1}$. In the present study, $\mathbf{1}$ activates HIF-1 under normoxic conditions and inhibits HIF-1 under hypoxic $\left(1 \% \mathrm{O}_{2}\right)$ conditions. The activation of HIF-1 by 1 coincides with increased mRNA levels of the three HIF-1 target genes examined. However, 1 did not inhibit hypoxic induction of the HIF-1 target genes. This discrepancy (inhibition of HIF-1 in the reporter assay versus no effect on HIF-1 target gene expression at the mRNA level) may be due to the partial inhibition of HIF-1 by 1 under hypoxic conditions. The residual HIF-1 activity is sufficient to induce the expression of HIF-1 target genes under hypoxic conditions. 


\section{Iron Overcomes ECG (1)-Induced HIF-1 Activation and HIF-1a Protein Stabilization}

Under normoxic conditions, HIF- $1 \alpha$ protein is post-translationally modified by prolyl hydroxylation prior to proteasomal degradation and by asparaginyl hydroxylation to prevent HIF-1 activation. ${ }^{15,16,18}$ Both prolyl and asparaginyl hydroxylases are dioxygenases, requiring iron(II) as a co-factor for activity. Since green tea catechins have been shown to form complexes with iron(III) in aqueous solution, ${ }^{33}$ we tested whether ECG-induced HIF-1 activation can be blocked by iron ions. In a T47D cell-based dual luciferase reporter assay for HIF-1 activity, iron(II) was added at a 1:1 and 3:1 stoichiometry prior to the addition of 1. The HIF-1 activating iron chelator desferrioxamine (DFO) ${ }^{19}$ was used as a positive control. As shown in Figure 4A, iron(II) completely inhibited ECG-induced HIF-1 activation at the concentration of $300 \mu \mathrm{M} \mathrm{FeSO}_{4}$ [3:1 stoichiometry of iron(II) to 1]. HIF-1 activation by DFO was blocked by iron(II) at both concentrations tested (100 and $300 \mu \mathrm{M}$ $\mathrm{FeSO}_{4}$ ). A more robust activation of HIF-1 was observed in the presence of $\mathbf{1}$ (3.4 times of that induced by DFO). The levels of nuclear HIF- $1 \alpha$ and HIF-1 $\beta$ proteins were also examined and the data shown in Figure 4B. Iron(II) blocked nuclear HIF-1 $\alpha$ protein induction by 1 ( $4 \mathrm{~h}$ incubation) without affecting the constitutively expressed HIF-1 $\beta$ protein. At the 1:1 stoichiometry, iron(II) blocked 1-induced accumulation of HIF-1 $\alpha$ protein (Figure 4B) but did not inhibit 1-activated HIF-1 (Figure 4A). A similar experiment was performed with the addition of iron(III) and the data shown in Figure 5. At the 3:1 stoichiometry ( $150 \mu \mathrm{M} \mathrm{Fe}_{2}\left(\mathrm{SO}_{4}\right)_{3}$ to $\left.100 \mu \mathrm{M} \mathrm{1}\right)$, iron(III) inhibited ECG-activated HIF-1 by $52 \%$. Meanwhile, iron(III) completely inhibited HIF-1 activation by DFO at both the 1:1 and 3:1 stoichiometry. Western blot analysis revealed that iron(III) blocked ECG-induced nuclear HIF-1 $\alpha$ protein accumulation without affecting the level of nuclear HIF-1 $\beta$ protein (Figure 5B).

Availability of the oxygen-regulated HIF-1 $\alpha$ subunit is critical to HIF-1 activity. Western blot and real time RT-PCR analysis revealed that 1 induces HIF- $1 \alpha$ protein without affecting HIF-1 $\alpha$ mRNA. An increase in translation or decrease in degradation (or both) can each lead to the accumulation of HIF- $1 \alpha$ protein. The following observations prompted us to test the hypothesis that $\mathbf{1}$ induces HIF-1 $\alpha$ protein by blocking their degradation: (1) compound $\mathbf{1}$ forms complexes with iron(III) ${ }^{33}$ and (2) compound $\mathbf{1}$ inhibits proteasome activity. ${ }^{34}$ If $\mathbf{1}$ prevents HIF-1 $\alpha$ protein degradation by inhibiting prolyl hydroxylases (through sequestering the co-factor iron), then addition of iron will overcome the action of $\mathbf{1}$. If $\mathbf{1}$ blocks HIF-1 $\alpha$ protein degradation by inhibiting proteasome activities, then addition of iron will not reverse the induction of HIF-1 $\alpha$ protein. In the present study, addition of iron in the form of either iron(II) or iron(III) each blocked ECG-induced HIF-1 $\alpha$ protein accumulation. These results support the hypothesis that $\mathbf{1}$ induces HIF- $1 \alpha$ protein by inhibiting HIF-1 $\alpha$ prolyl hydroxylases. The inhibitory effects of iron on 1-activated HIF-1 are dependent on the species of iron [iron(II) or iron(III)] and the ratio between iron and $\mathbf{1}$. At the stoichiometric ratio of 1:1, neither iron(II) nor iron(III) inhibited HIF-1 activation by $\mathbf{1}$, although they each blocked ECG-induced HIF-1 $\alpha$ protein accumulation. One possible scenario is that the intracellular iron concentration dropped below the threshold required for ECG-induced inhibition during extended incubation ( $16 \mathrm{~h}$ for HIF-1 activity versus $4 \mathrm{~h}$ for HIF- $1 \alpha$ protein level). At the stoichiometric ratio of 3:1, iron(II) completely blocked ECG-induced HIF-1 activation, while iron(III) only produced a 50\% decrease in HIF-1 activation. This may be due to the fact that iron(II) is a necessary co-factor for prolyl hydroxylase activity. Increasing levels of iron(II) directly enhance the enzymatic activity.

\section{Ascorbate and Trolox ${ }^{\circledR}$ Inhibit ECG (1)-induced HIF-1 Activation}

Reactive oxygen species (ROS) have been implicated in mediating HIF-1 activation and HIF-1 $\alpha$ protein stabilization induced by hypoxia, iron chelation, and other stimuli. ${ }^{35-39}$ The effects of two commonly used antioxidants (vitamin $\mathrm{C}$ and the water soluble vitamin $\mathrm{E}$ 
analogue Trolox ${ }^{\circledR}$ ) on ECG-induced HIF-1 activation were examined in T47D cells. The iron chelator DFO ${ }^{19}$ was included as a positive control for HIF-1 activation. A T47D cellbased dual luciferase reporter assay was used to monitor HIF-1 activity. Ascorbate (vitamin C) and Trolox ${ }^{\circledR}$ were added immediately before the addition of $\mathbf{1}$ or DFO (100 $\mu \mathrm{M}$ each). The normalized data are presented in Figure 6A. Ascorbate inhibited 1 activated HIF-1 by $86 \%$ and completely blocked DFO activated HIF-1. At the same concentration $(100 \mu \mathrm{M})$, Trolox ${ }^{\circledR}$ was less effective at inhibiting HIF-1 activation than ascorbate (31\% inhibition of $\mathbf{1}$ activated HIF-1, and $47 \%$ inhibition of DFO activated HIF-1). The effects of ascorbate and Trolox ${ }^{\circledR}$ on 1 induced accumulation of nuclear HIF-1 $\alpha$ protein were further examined and the Western blot data are shown in Figure 6B. Ascorbate or Trolox ${ }^{\circledR}$ alone exerted no effect on the levels of nuclear HIF-1 $\alpha$ or HIF-1 $\beta$ proteins. Ascorbate blocked 1 induced accumulation of nuclear HIF-1 $\alpha$ protein without affecting the HIF-1 $\beta$ protein level. In contrast, co-treatment with both Trolox ${ }^{\circledR}$ and 1 increased the nuclear HIF-1 $\alpha$ protein level in comparison to treatment with 1 alone. The observation that ascorbate blocks 1 induced HIF-1 activation supports the hypothesis that 1 activates HIF-1 by functioning as an iron chelator. A recent study has shown that ascorbate inhibits HIF-1 activation by iron chelators but does not similarly affect hypoxia-induced activation. ${ }^{20}$ Ascorbate promotes prolyl hydroxylation and ubiquitination of HIF-1 $\alpha$ protein in the presence of iron chelators. Our results suggest that $\mathbf{1}$ acts as an iron chelator to activate HIF-1 under normoxic conditions.

Of primary significance is the observation that $\mathbf{1}$ induces HIF- $1 \alpha$ protein and activates HIF-1 target genes under normoxic conditions in T47D human breast tumor cells. Results from both epidemiological and laboratory studies have, in general, supported the health promoting benefits of green tea consumption. ${ }^{10-12}$ However, mixed results have been obtained regarding the cancer chemopreventive effects of green tea in human studies. ${ }^{14}$ Our findings may provide one possible explanation for the mixed results obtained from some of these studies. "Undesired" physiological consequences such as the activation of tumor cell survival programs through HIF-1 may compromise the cancer chemopreventive effects of high-dose green tea extract supplementation. The overall cancer chemopreventive effect of green tea extract supplementation in clinical studies will ultimately be determined by the combination of both "beneficial" and "adverse" effects associated with the specific chemical entities contained in each product.

The abundance of each particular catechin varies between different types of tea and teabased supplements. In green tea, the concentration of 1 ranges from $0.97 \%$ to $7.83 \%$ (percentage weight of dry tea leaves), and the concentration of 2 ranges from $3.15 \%$ to $10.09 \% .^{12}$ The HIF-1 inducing activity of $\mathbf{1}$ is observed only at higher concentrations (i.e., $100 \mu \mathrm{M})$. This concentration is unlikely to be achieved in vivo by simply drinking green tea. One early study failed to detect $\mathbf{1}$ in the plasma samples of human subjects one hour after drinking one cup of powdered green tea (detection limit of 1: $1.0 \mathrm{ng} \mathrm{mL}^{-1}$ ). ${ }^{40}$ A later report indicates that compound $\mathbf{1}$ accumulates in a linear fashion in plasma, reaching a concentration of $50.6 \mathrm{nM} 24 \mathrm{~h}$ after consuming four doses of various black tea preparations. ${ }^{41}$ It is clear that this plasma concentration of $\mathbf{1}$ is far below that required to activate HIF-1 in vitro. However, the following factors can significantly increase the bioavailability of $\mathbf{1}$ and reduce the actual amount needed to activate HIF-1 in humans. First, commercial freezedried decaffeinated green tea solids (green tea extract, also known as GTE) contain a mixture of naturally occurring tea catechins. High dose or "mega dose" treatment regimens that use highly concentrated GTE products for cancer chemoprevention are becoming increasingly popular and involve ingesting multiple gram-level quantities repeatedly throughout the day. For example, the doses of GTE given to cancer patients in one Phase I clinical trial were as high as $13.6 \mathrm{~g}$ daily. ${ }^{13}$ The bioavailability of $\mathbf{1}$ following long-term GTE intake in large quantities may be significantly greater than the plasma level of $\mathbf{1}$ achieved from simply drinking tea. Currently, clinical data on plasma levels of ECG (free or 
conjugated forms) following GTE intake are not available in the published literature. Whether individuals consuming large quantities of GTE can accumulate 1 in tissues over a period of time and reach concentrations necessary for HIF-1 activation remains to be resolved. Second, other catechins such as EC (3) have been shown to exert synergistic effects with gallocatechins such as $\mathbf{1}$ and $\mathbf{2}$ in lung cancer cells. ${ }^{42}$ As a consequence, the actual quantity of $\mathbf{1}$ required to activate HIF-1 may be significantly lower if given in the form of GTE, in relation to the activation observed with purified compounds. Third, the flavonoid quercetin, also found in relatively high amounts in tea, has been shown to activate HIF-1 in endothelial cells. ${ }^{43}$ It is a logical extension to speculate that GTE may activate HIF-1 in an additive or even synergistic fashion with HIF-1 activating compounds such as 1 and quercetin, and other catechins that increase the bioavailability of active green tea components.

\section{Experimental Section}

\section{Cell Culture and General Experimental Procedures}

T47D cells (ATCC) were grown in DMEM/F12 medium (JRH Biosciences) supplemented with $10 \%(\mathrm{v} / \mathrm{v})$ fetal bovine serum (FBS) (Hyclone), 50 units $\mathrm{mL}^{-1}$ penicillin $\mathrm{G}$ (sodium salt) and $50 \mu \mathrm{g} \mathrm{mL}^{-1}$ streptomycin sulfate (referred to as "Pen/Strep") (Life Technologies) in a humidified atmosphere $\left(5 \% \mathrm{CO}_{2}: 95 \%\right.$ air) at $37^{\circ} \mathrm{C}$. Compounds 1-6 were from Sigma. A stock solution of $10 \mathrm{mg} \mathrm{mL}^{-1}$ was prepared in $95 \%$ ethanol and stored at $-80{ }^{\circ} \mathrm{C}$. The stock solutions were thawed to room temperature, dried under argon, and resuspended in DMEM/F12 medium supplemented with Pen/Strep before use. Ascorbate (Sigma) was freshly prepared each time. Unless otherwise specified, all the compounds were purchased from Sigma.

\section{Transient Transfection and Reporter Assays}

For T47D cell-based reporter assays employing the pTK-HRE3-luc reporter ${ }^{24}$ or the control construct pGL3-Control (Promega), both the transfection and the luciferase reporter assay were performed as described. ${ }^{25}$ Dual luciferase assay with the pTK-HRE3-luc reporter and the internal control pRL-TK (Promega) was performed with the following modifications: (1) a mixture of pTK-HRE3-luc $\left(50 \mu \mathrm{g} \mathrm{mL}^{-1}\right)$ and pRL-TK $\left(5 \mu \mathrm{gL}^{-1}\right)$ was used to transiently transfect T47D cells by electroporation, and (2) a dual luciferase assay system (Promega) was employed to determine luciferase activities following manufacturer's instructions. Firefly luciferase activity was normalized with that of the Renilla luciferase.

\section{Extraction and TLC Analysis}

Exponentially growing T47D cells were seeded at the density of $9.375 \times 10^{4}$ cells $\mathrm{cm}^{-2}$ into $150 \mathrm{~mm}$ diameter tissue culture plates. After $24 \mathrm{~h}$, an equal volume of serum-free DMEM/ F12 medium containing Pen/Strep and the test compound was added and incubated for 30 min before exposure to hypoxia $\left(1 \% \mathrm{O}_{2}\right)$. Following a $16 \mathrm{~h}$ incubation, the conditioned media were collected and immediately extracted. For each sample, $30 \mathrm{~mL}$ EtOAc was used to extract $25 \mathrm{~mL}$ of the conditioned media (three times total). The combined extracts (approximately $90 \mathrm{~mL}$ ) were dried over $\mathrm{MgSO}_{4}$. Following filtration, the solvents were removed in vacuo. The residue was reconstituted with $0.1 \mathrm{~mL} \mathrm{MeOH}$ and subjected to TLC analysis (Alugram ${ }^{\circledR}$ Sil G/UV 254 silica gel sheets with benzene-EtOAc-AcOH (3:6:1) as the solvent system). The TLC plates were visualized under $\mathrm{UV}_{254}$, and then sprayed with $10 \%$ ferric chloride in EtOH and heated. Compounds $\mathbf{1}$ and $\mathbf{2}$ were detected at $R_{\mathrm{f}}$ values of 0.34 and 0.23 , respectively. The stability of $\mathbf{2}$ was analyzed in the absence of cells, using the same protocol as that used in the presence of cells. As an extraction control, 2 was mixed with DMEM/F12 medium containing 5\% FBS and Pen/Strep immediately before extraction. The extraction and TLC analysis were performed as described. 


\section{RNA Extraction and Quantitative Real Time RT-PCR}

Total RNA samples were extracted from the control and treated T47D cells using the RNeasy kit (QIAGEN) immediately following treatments. The concentration and purity of RNA samples were determined spectrophotometrically by absorbance at 230, 260, 280, and $320 \mathrm{~nm}$, and the integrity confirmed by agarose gel electrophoresis. Synthesis of the first strand cDNAs, quantitative real-time PCR reactions, and data analysis were performed as described. ${ }^{26}$ The following gene-specific primer pairs were used: hifla $5^{\prime}$ -

CTGATATTAAACCTAAATGTTCTGCCTACC-3', 5'-

CAGTCTGCTCAAAATATCTTTATACCAAC-3'; glut 1 5'-

CCTAAGGATCTCTCAGGAGCACAG-3', 5'-TCAGGTTTGGAAGTCTCATCCAG-3'; vegf 5'-TGTATTTGACTGCTGTGGACTTGAG-3', 5'-

TCAGGATCTGAGTGGGAACATTC-3'; cdknla 5'-

TGGCAGTAGAGGCTATGGACAG-3', 5'-CTCCCAGCCCCATATGAGC-3'; and $18 \mathrm{~S}$ rRNA 5'-CGGAGGTTCGAAGACGATCA-3', 5'-CATCGTTTATGGTCGGAACTACG-3' .

\section{Nuclear Extract Preparation and Western Blot Analysis}

Ten million exponentially growing T47D cells were plated into a $100 \mathrm{~mm}$ diameter tissue culture plate (Corning) in a volume of $10 \mathrm{~mL}$ DMEM/F12 medium supplemented with $10 \%$ (v/v) FBS and Pen/Strep. After incubating overnight at $37^{\circ} \mathrm{C}$, test compounds were added and incubated for another $30 \mathrm{~min}$ at $37^{\circ} \mathrm{C}$. The cells were then exposed to normoxic conditions ( $5 \% \mathrm{CO}_{2}: 95 \%$ air), hypoxic conditions $\left(5 \% \mathrm{CO}_{2}: 1 \% \mathrm{O}_{2}: 94 \% \mathrm{~N}_{2}\right.$ ), or other test reagents that activate HIF-1 for another $4 \mathrm{~h}$ at $37^{\circ} \mathrm{C}$. Nuclear extract preparation and Western blot analysis of HIF- $1 \alpha$ and HIF- $1 \beta$ proteins were performed as described. ${ }^{25}$

\section{ELISA Assay for Human VEGF Protein}

Exponentially grown T47D cells were plated at the density of $3.6 \times 10^{5}$ cells per well in a volume of $1 \mathrm{~mL}$ DMEM/F12 medium supplemented with 10\% (v/v) FBS and Pen/Strep into 12-well plates (Corning). After incubating for $24 \mathrm{~h}$, test compounds dissolved in serum-free DMEM/F12 medium with Pen/Strep were added in a volume of $1 \mathrm{~mL}$. Following a $30 \mathrm{~min}$ incubation at $37{ }^{\circ} \mathrm{C}$, the cells were exposed to normoxic $\left(5 \% \mathrm{CO}_{2}: 95 \%\right.$ air) or hypoxic $(5 \%$ $\mathrm{CO}_{2}: 1 \% \mathrm{O}_{2}: 94 \% \mathrm{~N}_{2}$ ) conditions for another $16 \mathrm{~h}$. The conditioned media were removed, the cells washed twice with ice-cold 1x PBS, and lysed in $250 \mu \mathrm{L}$ of $20 \mathrm{mM}$ Tris, $\mathrm{pH}$ 7.4, 0.5\% (v/v) NP-40 (Calbiochem) and a protease inhibitor cocktail (Sigma, Catalog No. P2714). The cell lysate was transferred to a microcentrifuge tube, vortexed for $20 \mathrm{sec}$, spun at 14,000 rpm (Centrifuge 5415C, Eppendorf) for $10 \mathrm{~min}$ at $4{ }^{\circ} \mathrm{C}$, and the supernatant transferred to a new tube. The levels of VEGF proteins in the cell lysate were determined using an ELISA assay for human VEGF proteins (R\&D Systems) as described ${ }^{25}$ and the protein concentration in the cell lysate were determined using a micro BCA assay kit (Pierce).

\section{Statistical Analysis}

Data comparisons were performed using ANOVA and Fisher's PLSD post hoc analyses (StatView ${ }^{\circledR}$ Software Version 5.01, SAS Institute Inc). Differences were considered significant when $p<0.05$.

\section{Supplementary Material}

Refer to Web version on PubMed Central for supplementary material.

\section{Acknowledgments}

We thank Dr. Steven L. McKnight (University of Texas Southwestern Medical Center at Dallas) for the pTKHRE3-luc construct and Ms. Melanie Mask (USDA/ARS) for technical assistance with quantitative real-time RT- 
PCR assays. This work was supported in part by the National Institutes of Health-National Cancer Institute CA-98787-01 (D.G.N.) and the DOD/2000-Breast Cancer Research Program DAMB17-01-1-0566 (D.G.N.). The U.S. Army Medical Research Acquisition Activity, 820 Chandler Street, Fort Detrick, MD 21702-5014 is the awarding and administering acquisition office. The content herein reported does not necessarily reflect the position or the policy of the Government, and no official endorsement should be inferred. Additional support was provided by the University of Mississippi Faculty Research Program (Y.-D.Z.), NOAA NURP/NIUST NA16RU1496, and USDA/Agricultural Research Service Specific Cooperative Agreement No. 58-6408-2-0009.

\section{References and Notes}

1. Harris AL. Nature Rev Cancer 2002;2:38-47. [PubMed: 11902584]

2. Semenza GL. Nature Rev Cancer 2003;3:721-732. [PubMed: 13130303]

3. Zhong H, De Marzo AM, Laughner E, Lim M, Hilton DA, Zagzag D, Buechler P, Isaacs WB, Semenza GL, Simons JW. Cancer Res 1999;59:5830-5835. [PubMed: 10582706]

4. Jiang BH, Agani F, Passaniti A, Semenza GL. Cancer Res 1997;57:5328-5335. [PubMed: 9393757]

5. Maxwell PH, Dachs GU, Gleadle JM, Nicholls LG, Harris AL, Stratford IJ, Hankinson O, Pugh CW, Ratcliffe PJ. Proc Natl Acad Sci USA 1997;94:8104-8109. [PubMed: 9223322]

6. Ryan HE, Lo J, Johnson RS. EMBO J 1998;17:3005-3015. [PubMed: 9606183]

7. Ryan HE, Poloni M, McNulty W, Elson D, Gassmann M, Arbeit JM, Johnson RS. Cancer Res 2000;60:4010-4015. [PubMed: 10945599]

8. Hopfl G, Wenger RH, Ziegler U, Stallmach T, Gardelle O, Achermann R, Wergin M, Kaser-Hotz B, Saunders HM, Williams KJ, Stratford IJ, Gassmann M, Desbaillets I. Cancer Res 2002;62:29622970. [PubMed: 12019179]

9. Giaccia A, Siim BG, Johnson RS. Nature Rev Drug Discov 2003;2:803-811. [PubMed: 14526383]

10. Fujiki H. J Cancer Res Clin Oncol 1999;125:589-597. [PubMed: 10541965]

11. Mukhtar H, Ahmad N. Toxicol Sci 1999;52(Suppl):111-117. [PubMed: 10630599]

12. Demeule M, Michaud-Levesque J, Annabi B, Gingras D, Boivin D, Jodoin J, Lamy S, Bertrand Y, Beliveau R. Curr Med Chem Anti-Cancer Agents 2002;2:441-463.

13. Pisters KM, Newman RA, Coldman B, Shin DM, Khuri FR, Hong WK, Glisson BS, Lee JS. J Clin Oncol 2001;19:1830-1838. [PubMed: 11251015]

14. Bushman JL. Nutr Cancer 1998;31:151-159. [PubMed: 9795966]

15. Ivan M, Kondo K, Yang H, Kim W, Valiando J, Ohh M, Salic A, Asara JM, Lane WS, Kaelin WG Jr. Science 2001;292:464-468. [PubMed: 11292862]

16. Jaakkola P, Mole DR, Tian YM, Wilson MI, Gielbert J, Gaskell SJ, Kriegsheim AV, Hebestreit HF, Mukherji M, Schofield CJ, Maxwell PH, Pugh CW, Ratcliffe PJ. Science 2001;292:468-472. [PubMed: 11292861]

17. Maxwell PH, Wiesener MS, Chang GW, Clifford SC, Vaux EC, Cockman ME, Wykoff CC, Pugh CW, Maher ER, Ratcliffe PJ. Nature 1999;399:271-275. [PubMed: 10353251]

18. Lando D, Peet DJ, Whelan DA, Gorman JJ, Whitelaw ML. Science 2002;295:858-861. [PubMed: 11823643]

19. Wang GL, Semenza GL. Blood 1993;82:3610-3615. [PubMed: 8260699]

20. Knowles HJ, Raval RR, Harris AL, Ratcliffe PJ. Cancer Res 2003;63:1764-1768. [PubMed: 12702559]

21. Chong TW, Horwitz LD, Moore JW, Sowter HM, Harris AL. Cancer Res 2002;62:6924-6927. [PubMed: 12460908]

22. Linden T, Katschinski DM, Eckhardt K, Scheid A, Pagel H, Wenger RH. FASEB J 2003;17:761763. [PubMed: 12594177]

23. Mabjeesh NJ, Willard MT, Harris WB, Sun HY, Wang R, Zhong H, Umbreit JN, Simons JW. Biochem Biophys Res Commun 2003;303:279-286. [PubMed: 12646199]

24. Tian H, McKnight SL, Russell DW. Genes Dev 1997;11:72-82. [PubMed: 9000051]

25. Hodges TW, Hossain CF, Kim YP, Zhou YD, Nagle DG. J Nat Prod 2004;67:767-771. [PubMed: 15165135]

26. Agarwal AK, Rogers PD, Baerson SR, Jacob MR, Barker KS, Cleary JD, Walker LA, Nagle DG, Clark AM. J Biol Chem 2003;278:34998-35015. [PubMed: 12824174] 
27. Cao Y, Cao R. Nature 2000;398:381. [PubMed: 10201368]

28. Jung YD, Kim MS, Shin BA, Chay KO, Ahn BW, Liu W, Bucana CD, Gallick GE, Ellis LM. Br J Cancer 2001;84:844-850. [PubMed: 11259102]

29. Sartippour MR, Shao ZM, Heber D, Beatty P, Zhang L, Liu C, Ellis L, Liu W, Go VL, Brooks MN. J Nutr 2002;132:2307-2311. [PubMed: 12163680]

30. Lamy S, Gingras D, Beliveau R. Cancer Res 2002;62:381-385. [PubMed: 11809684]

31. Garbisa S, Biggin S, Cavallarin N, Sartor L, Benelli R, Albini A. Nature Med 1999;5:1216. [PubMed: 10545959]

32. Demeule M, Brossard M, Page M, Gingras D, Beliveau R. Biochim Biophys Acta 2000;1478:5160. [PubMed: 10719174]

33. Jovanovic SV, Simic MG, Steenken S, Hara Y. J Chem Soc Perkin Trans 1998;2:2365-2369.

34. Nam S, Smith DM, Dou QP. J Biol Chem 2001;276:13322-13330. [PubMed: 11278274]

35. Chandel NS, Maltepe E, Goldwasser E, Mathieu CE, Simon MC, Schumacker PT. Proc Natl Acad Sci USA 1998;95:11715-11720. [PubMed: 9751731]

36. Richard DE, Berra E, Pouyssegur J. J Biol Chem 2000;275:26765-26771. [PubMed: 10837481]

37. Gao N, Ding M, Zheng JZ, Zhang Z, Leonard SS, Liu KJ, Shi X, Jiang BH. J Biol Chem 2002;277:31963-31971. [PubMed: 12070140]

38. Page EL, Robitaille GA, Pouyssegur J, Richard DE. J Biol Chem 2000;277:48403-48409. [PubMed: 12379645]

39. Shatrov VA, Sumbayev VV, Zhou J, Brune B. Blood 2003;101:4847-4849. [PubMed: 12586627]

40. Lee MJ, Wang ZY, Li H, Chen L, Sun Y, Gobbo S, Balentine DA, Yang CS. Cancer Epidemiol Biomarkers Prev 1995;4:393-399. [PubMed: 7655336]

41. Warden BA, Smith LS, Beecher GR, Balentine DA, Clevidence BA. J Nutr 2001;131:1731-1737. [PubMed: 11385060]

42. Suganuma M, Okabe S, Kai Y, Sueoka N, Sueoka E, Fujiki H. Cancer Res 1999;59:44-47. [PubMed: 9892181]

43. Wilson WJ, Poellinger L. Biochem Biophys Res Commun 2002;293:446-450. [PubMed: 12054621] 

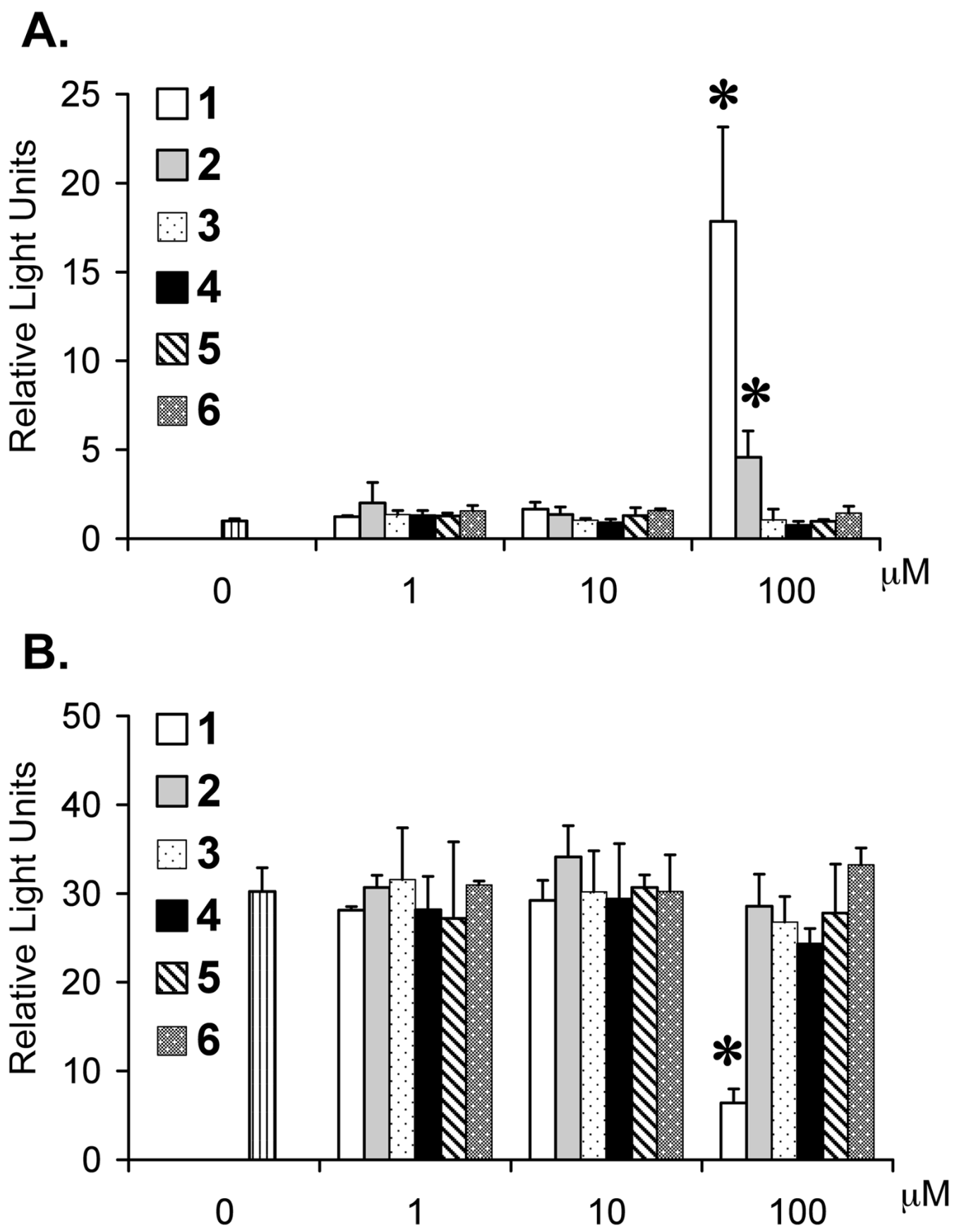

Figure 1.

Structure activity relationship of green tea catechins and related compounds that regulate HIF-1 in T47D cells. Cell-based reporter assay data that measures HIF-1 activity in the presence (and absence) of test compounds under normoxic conditions $(A)$ and hypoxic conditions $\left(1 \% \mathrm{O}_{2}\right)(B)$. Averages from one representative experiment performed in quadruplicate are shown and the bars represent standard deviation. An asterisk (*) indicates $p<0.05$ when compared to the control. 
A.

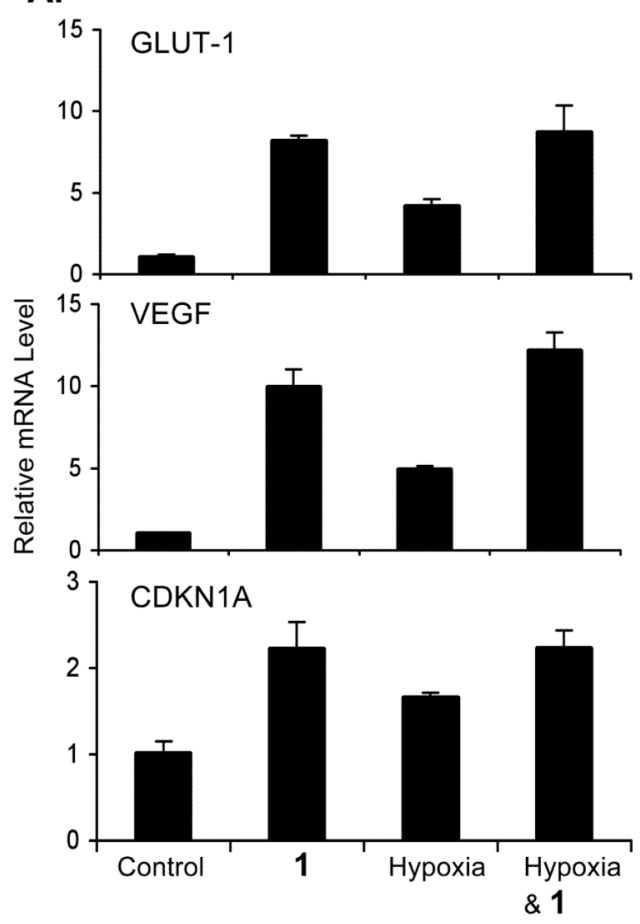

B.

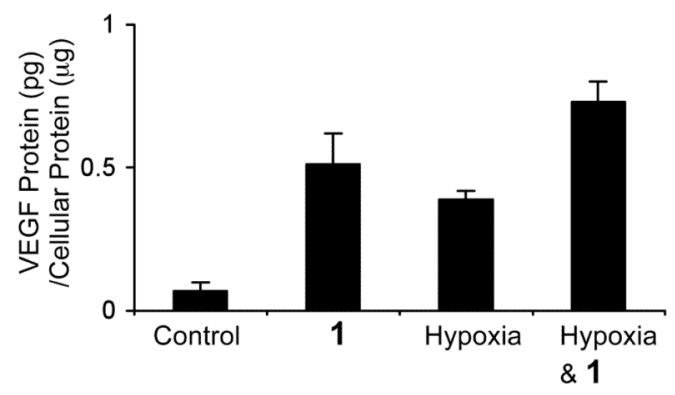

Figure 2.

Compound 1 induces HIF-1 target gene expression in T47D cells under normoxic conditions. Quantitative real time RT-PCR analysis of GLUT-1, VEGF, and CDKN1A mRNA levels upon treatment with $1(100 \mu \mathrm{M})$, hypoxia $\left(1 \% \mathrm{O}_{2}\right)$, and both for $16 \mathrm{~h}(A)$. The data (mean $\pm \mathrm{SD}$ ) are normalized to an internal control (18S rRNA) and the relative expression level determined by the $\Delta \Delta \mathrm{C}_{\mathrm{T}}$ method. ${ }^{26}$ The levels of VEGF proteins in whole cell lysate were determined by ELISA and normalized to the amount of protein $(B)$. The treatments are the same as $(A)$. Bars represent standard deviation from one representative experiment performed in triplicate. 


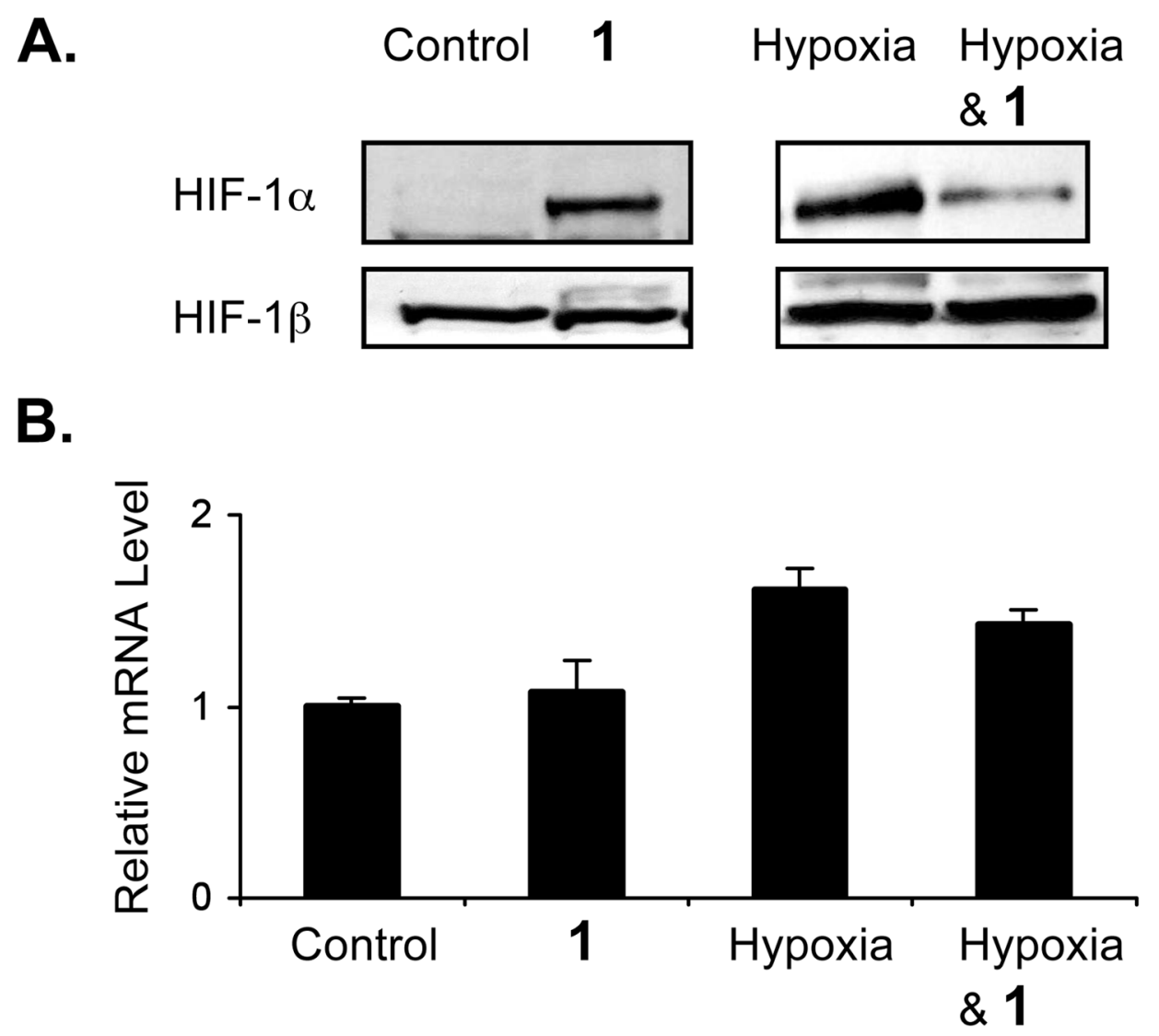

Figure 3.

Compound 1 regulates nuclear HIF-1 $\alpha$ protein availability in T47D cells. Western blot results of nuclear extract samples for HIF- $1 \alpha$ and HIF- $1 \beta$ proteins following $4 \mathrm{~h}$ treatment with $1(100 \mu \mathrm{M})$ under normoxic or hypoxic $\left(1 \% \mathrm{O}_{2}\right)$ conditions $(A)$. Results from quantitative real time RT-PCR analysis of HIF- $1 \alpha$ mRNA levels $(B)$. Compound treatment and data processing of the real time RT-PCR studies are the same as that described in Figure $2 \mathrm{~A}$. 


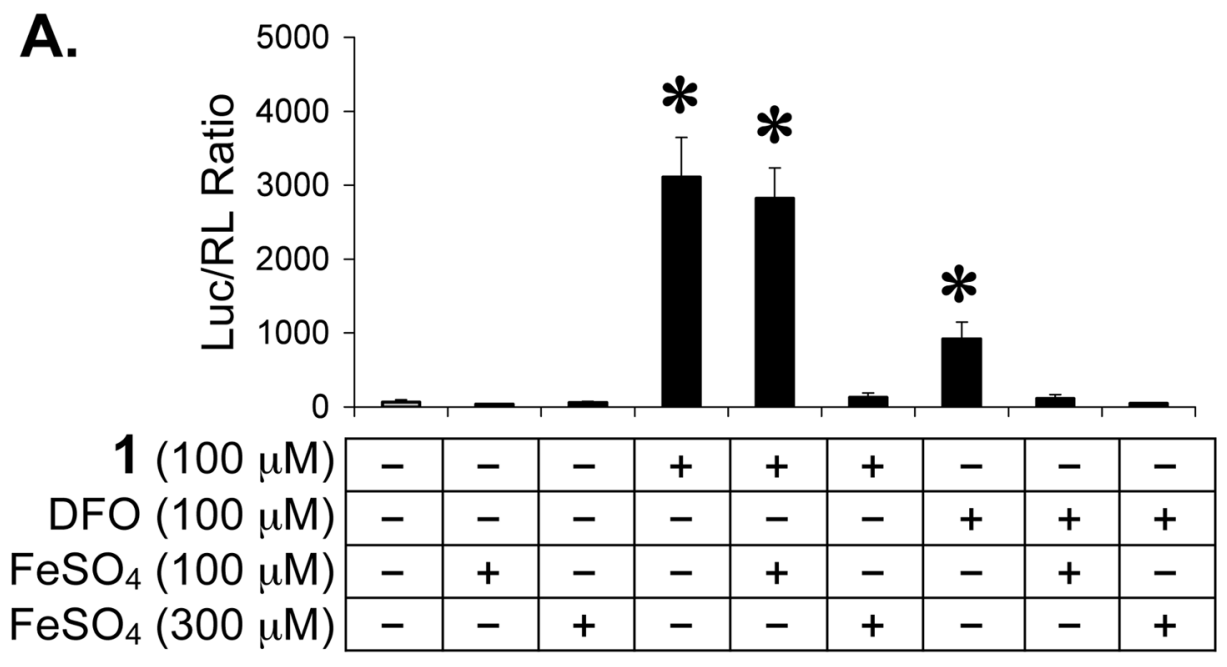

B.

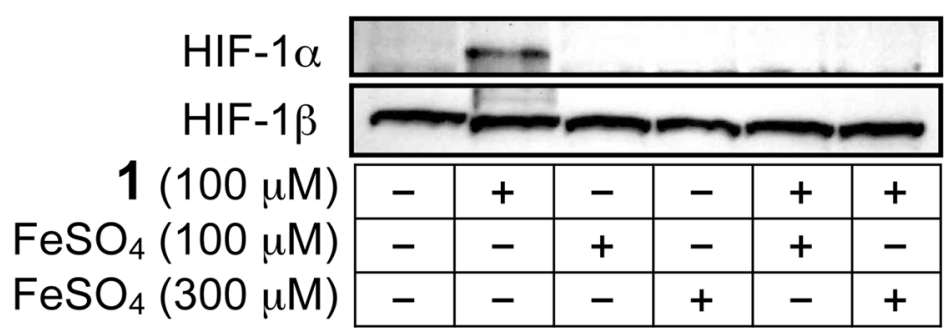

Figure 4.

Iron (II) blocks HIF-1 activation by 1 under normoxic conditions. Reporter assay data showing that addition of iron(II) inhibits HIF-1 activation by $\mathbf{1}$ and by the iron chelator DFO in a dose dependent manner $(A)$. Averages from one representative experiment performed in quadruplicate are shown and the bars represent standard deviation. An asterisk $(*)$ indicates $p<0.05$ when compared to the control. HIF- $1 \alpha$ and HIF- $1 \beta$ proteins in the nuclear extract samples were detected by Western blot $(B)$. These extracts were prepared from T47D cells treated with $1, \mathrm{FeSO}_{4}$, or both, at the indicated concentrations for $4 \mathrm{~h}$. 

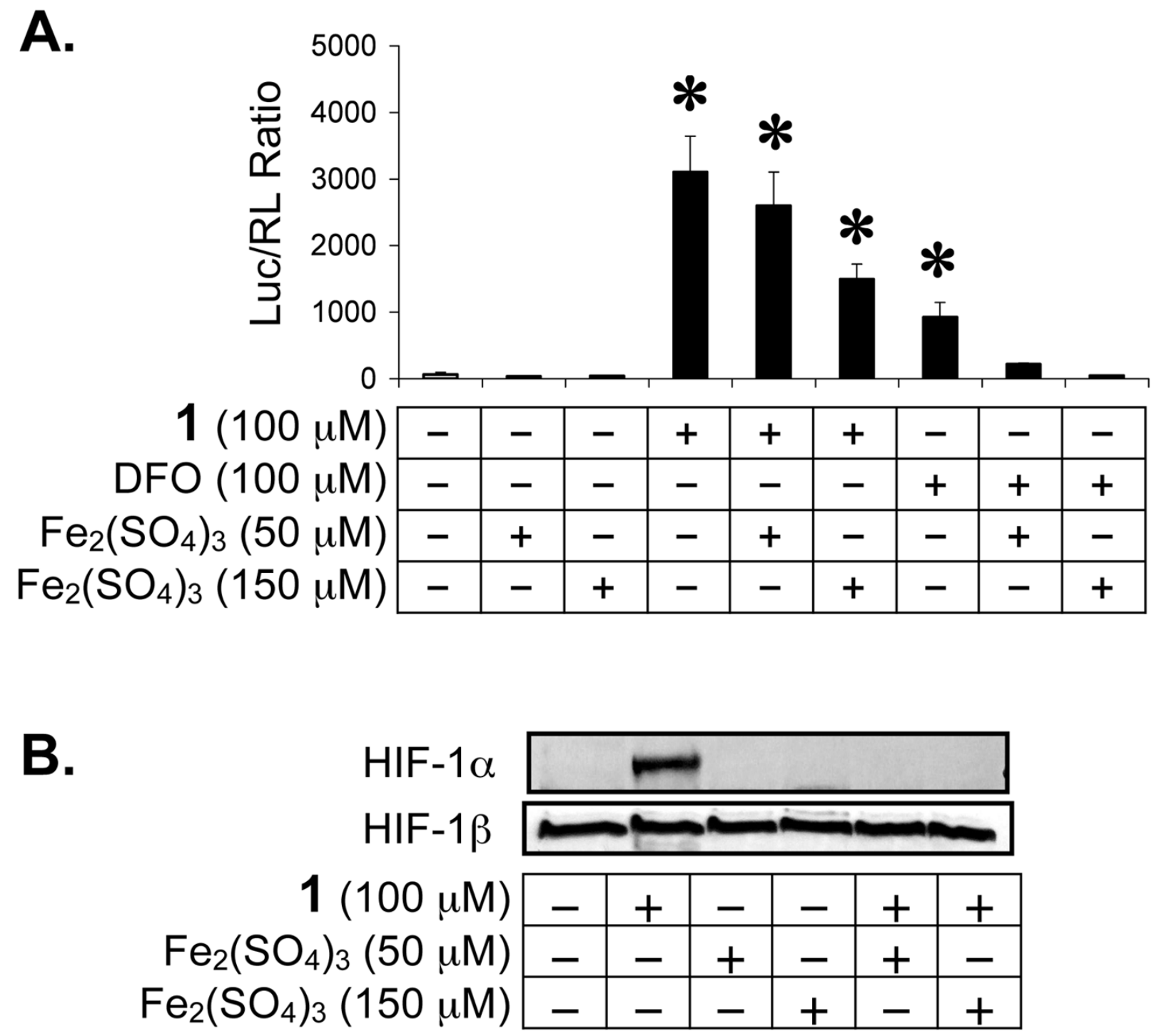

Figure 5.

Iron (III) inhibits HIF-1 activation by 1 under normoxic conditions. Reporter assay data (A) and Western blot results $(B)$. Compound treatment and data presentation are the same as described in Figure 4, except that $\mathrm{Fe}_{2}\left(\mathrm{SO}_{4}\right)_{3}$ was used instead of $\mathrm{FeSO}_{4}$. 


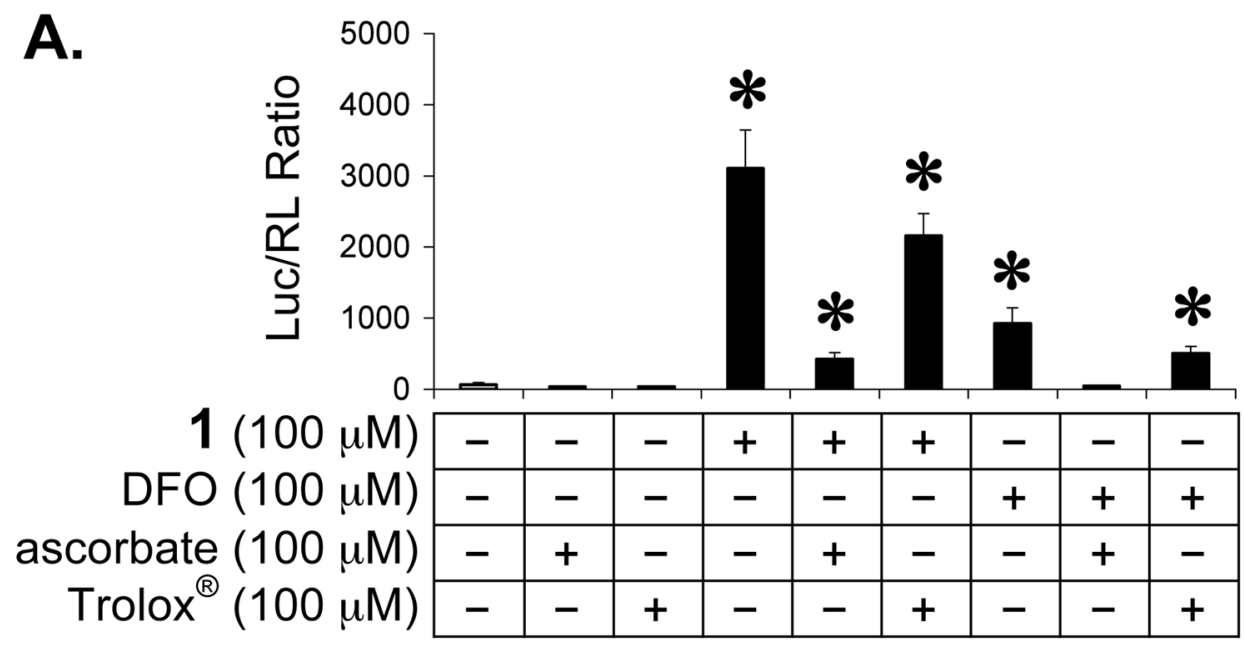

B.

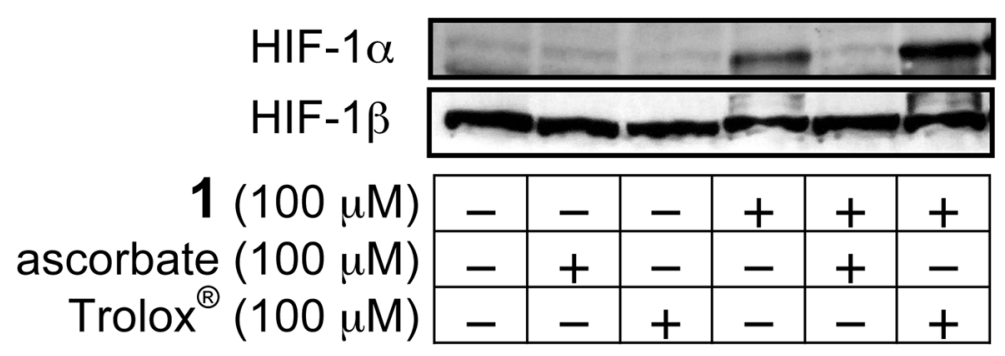

Figure 6.

Ascorbate and Trolox ${ }^{\circledR}$ reduce HIF-1 activation by 1 under normoxic conditions. Reporter assay data $(A)$ and Western blot results $(B)$. Compound treatment time and data presentation are the same as described in Figure 4. 